\title{
Monocyte chemoattractant protein 1: a possible link between visceral adipose tissue-associated inflammation and subclinical echocardiographic abnormalities in uncomplicated obesity
}

Alexis E Malavazos, Emanuele Cereda, Lelio Morricone, Calin Coman ${ }^{2}$, Massimiliano M Corsi ${ }^{1}$ and Bruno Ambrosi

Endocrinology Unit, Department of Medical and Surgical Sciences, and ${ }^{1}$ Laboratory of Clinical Pathology, Institute of General Pathology, University of Milano, Policlinico San Donato, Via Morandi 30, I-20097 San Donato, Milano, Italy and ${ }^{2}$ Echocardiographic Unit, Policlinico San Donato, San Donato Milanese, Milano, Italy

(Correspondence should be addressed to B Ambrosi; Email: bruno.ambrosi@unimi.it)

\begin{abstract}
Objective: Obesity can be considered a state of chronic, low-grade inflammation. Particularly, visceral adipose tissue (VAT) seems to be an active compartment in pro-inflammatory molecule secretion. Adipocytes and VAT are able to produce large amounts of monocyte chemoattractant protein 1 (MCP-1), a chemokine directly involved in ventricular remodeling.

Design: In this study, the possible existence of a correlation between MCP-1, abdominal fat accumulation and echocardiographic abnormalities in uncomplicated obesity was investigated.

Methods: Echocardiographic parameters, MCP-1 and C-reactive protein (CRP) levels were assessed in 27 normotensive obese women of fertile age (body mass index $43.5 \pm 4.8 \mathrm{~kg} / \mathrm{m}^{2}$, mean \pm S.D.) and 15 normal weight women. Visceral fat (VAT) in the obese group was assessed by computed tomography. Results: Obese patients had higher MCP-1 $(P<0.0001)$ and CRP $(P<0.0001)$ levels than controls. MCP-1 levels were correlated with VAT area $(r=0.57, P<0.0001)$, CRP $(P<0.0001)$, left ventricular mass (LVM) $(P<0.02)$, LVM indexed for height $(P<0.03)$, end-diastolic posterior wall $(P<0.005)$, relative wall thickness $(P<0.01)$, early diastolic filling wave velocity $(P<0.01)$, isovolumetric relaxation time $(P<0.001)$ and deceleration time $(P<0,01)$. Obese patients with greater amounts of VAT $\left(>130 \mathrm{~cm}^{2}\right)$ presented higher MCP-1 $(P<0.0001)$ and CRP levels $(P<0.04)$ than those with a lower degree of abdominal adiposity.

Conclusions: MCP-1 levels and visceral adipose tissue seem to be associated with some morphological and functional echocardiographic abnormalities and support a role for visceral fat in predisposing the subject to cardiac dysfunction, possibly through a low-grade state of inflammation.
\end{abstract}

European Journal of Endocrinology 153 871-877

\section{Introduction}

Adipose tissue is far from being considered a simple fatstorage depot. Several studies demonstrate that it should be given the title of endocrine organ, able to produce and release a great variety of cytokines and hormone-like proteins such as tumor necrosis factoralpha, interleukin-6, monocyte chemoattractant protein 1 (MCP-1) and the newly isolated protein, visfatin $(1-4)$. Most of these mediators exert a systemic action as inflammatory pathway activators. In particular, MCP-1 has been implicated in the pathogenesis of several cardiovascular disorders such as chronic heart failure and myocarditis $(5,6)$. In fact, MCP-1 can directly affect cardiomyocytes and this observation introduces this chemokine as a potential enhancer of inflammatory responses within the myocardium (7). Elevated myocardial MCP-1 levels may play an important role in the pathogenesis of ventricular remodeling after myocardial infarction by inducing myocyte hypertrophy and interstitial fibrosis (8). MCP-1 is a monomeric polypeptide belonging to the chemokine family that plays a crucial role in monocyte recruitment (9).

Adipose tissue macrophage infiltration has been demonstrated to increase proportionally in relation to adiposity (10) and to participate in inflammatory pathways that are activated in this body compartment in the obese state $(10,11)$.

Bruun et al. have recently demonstrated that MCP-1 release is higher in visceral adipose tissue (VAT) compared with subcutaneous adipose tissue (SAT), suggesting the former as a major source of the increased levels of MCP-1 (12).

Given that human adipose tissue is also metabolically active and able to secrete MCP-1 (13), it has recently been reported that reduction in visceral fat is directly correlated to a decrease in MCP-1 levels (14), supporting a role for VAT in the systemic inflammatory condition. At present, to our knowledge, literature about the correlation between MCP-1 and abdominal 
adiposity is still scarce and poor evidence has been provided about a correlation between MCP-1 secretion and the VAT entity in humans (12).

It has been shown that intra-abdominal fat is correlated with subclinical cardiac alterations (15) and reduction of abdominal adiposity reduces the secretion of cytokines and improves cardiac function (16).

With this background it has been supposed that increased MCP-1 secretion, possibly by the visceral tissue, might influence cardiac morphology and function. Therefore, the aim of this study was to evaluate the possible existence of a correlation between MCP-1 and echocardiographic abnormalities by assessing their relation with VAT in uncomplicated obese women.

\section{Subjects and methods}

The study was performed according to the recommendations of the Declaration of Helsinki and all the subjects recruited gave informed consent to the examination protocol.

\section{Subjects}

Twenty-seven obese female patients of fertile age (mean age $33.3 \pm 8.3$ years (range, 21 to 50 years), mean body mass index (BMI) $43.5 \pm 4.8 \mathrm{~kg} / \mathrm{m}^{2}$ (range, $\left.36.7-54.6 \mathrm{~kg} / \mathrm{m}^{2}\right)$ ) were recruited and underwent physical examination. None of the patients had a past history of heart, hepatic, renal, pulmonary, endocrine or neoplastic disease. They were all non-smokers (non-smoking habit for at least five years). No chronic inflammatory disease nor minor infection was detectable at the time of the study. None of the subjects was treated with drugs that could interfere with the study (statins, fibrates, thiazolidinediones, steroids, hormone replacement or nonsteroidal anti-inflammatory drugs). The patients were compared with 15 healthy normotensive and normal weight control women matched for age and height (mean age 36.8 \pm 8.2 years (range, 23 to 49 years); mean BMI $\left.22.6 \pm 1.7 \mathrm{~kg} / \mathrm{m}^{2}\right)$.

\section{Anthropometric measurement and VAT assessment}

All the subjects were measured for height, weight, waist circumference, hip circumference, and BMI and waist/ hip ratio (WHR) were calculated. Fat mass and fat-free mass were estimated by bioelectrical impedance analysis (BIA 101-S; Akern, Florence, Italy).

Adipose tissue accumulation in the obese group was assessed by computed tomography at the L4-L5 level. VAT and SAT areas were measured using a single scan at the L4 level and computed with attenuation values of between -150 and -50 Hounsfield units. The VAT/SAT area ratio was calculated. Abdominal sagittal diameter in centimeters at the L4 level was also measured.

\section{Echocardiographic measurements}

The echocardiographic variables were collected using an M-mode color-doppler VSF (Vingmed-System Five; General Electric, Horten, Norway) with a 2.5- to $3.5-\mathrm{MHz}$ transducer probe by the same experienced physician. Recordings were made on the left lateral decubitus position after $10 \mathrm{~min}$ supine rest. M-mode tracings were obtained from the parasternal left ventricular short-axis view and at a paper speed of $50 \mathrm{~mm} / \mathrm{s}$, and recordings were read by two different examiners blind to the biochemical data. End systolic and diastolic left ventricular volume (LVEDV), diameter (LVEDD), septum and posterior wall (PW) thickness and end systolic left atrium were measured according to the methods of the American Society of Echocardiography (17). Left ventricular mass (LVM) was calculated using the Penn convention (18) and normalized for height (in meters) to the 2.7 power $\left(\mathrm{LVMh}^{2.7}\right)$ to take into account the independent effect of obesity on left ventricle (LV) geometry (19). The relative wall thickness (RWT) was calculated as $2 \times$ posterior wall/LV end-diastolic diameter (2PW/LVEDD). LV diastolic function correlates (early (E) and atrial (A) diastolic filling wave velocities, E/A ratio, isovolumetric relaxation time (IVRT)) were evaluated using pulse-wave Doppler echocardiography.

\section{Blood samples}

Blood samples were drawn after overnight fasting for serum glucose, insulin (immunoradiometric assay), total cholesterol, high density lipoprotein cholesterol and triglycerides. Low density lipoprotein values were obtained according to the Friedewald formula. Insulin sensitivity in the fasting state was assessed with homeostasis model assessment (HOMA) and QUICKI (20). Serum samples were stored at $-20{ }^{\circ} \mathrm{C}$ and then assayed for C-reactive protein (CRP) levels by immunoturbidimetric assay (Roche-Hitachi Maanheim, Germany). Plasma MCP-1 concentrations were evaluated using a Quantikine Enzyme-Linked ImmunoSorbent Assay (ELISA) kit (R\&D Systems, Abingdom, UK/ Inc., Minneapolis, MA, USA). According to the manufacturer's recommendations, $100 \mu \mathrm{l}$ assay diluent (buffered protein base) and $100 \mu \mathrm{l}$ sample or standard were added to each well of a polystyrene microplate coated with a monoclonal murine antibody against MCP-1. Each sample, standard and blank was assayed in duplicate. After incubating at room temperature for $2 \mathrm{~h}$ and washing with a buffered surfactant solution, $200 \mu \mathrm{l}$ polyclonal antibody against MCP-1 conjugated with horseradish peroxidase were added to each well, incubated and washed again. Then $200 \mu$ l substrate solution (hydrogen peroxide and tetramethylbenzidine 
as chromogen) were added to each well and incubated at room temperature for 20 min protected from light. Finally, $50 \mu \mathrm{l}$ stop solution ( $2 \mathrm{M}$ sulfuric acid) were added to each well and the absorbance was determined within 30 min using a microplate reader (EL-800, BioTEK Instruments, Inc., Winooski, VT, USA) set to $450 \mathrm{~nm}$. The minimum detectable dose was determined to be $5 \mathrm{pg} / \mathrm{ml}$.

\section{Statistical analysis}

Data are presented as means \pm standard deviation (S.D.). Comparisons between the groups were analyzed using Student's two-tailed t-test. An unweighted linear regression model was used to evaluate the relationship between variables and stepwise regression analysis was used to assess the association between the MCP-1 values and indices of fat distribution. The relationship between MCP-1 and echocardiographic parameters was also evaluated after correction for VAT and CRP by a partial correlation method. All statistical analyses were performed by STATISTIX 4.1 (Analytical Software, Tallahassee, FL, USA). The significance level was established at $P<0.05$.

\section{Results}

\section{MCP-1, CRP and clinical-anthropometric variables}

Anthropometric and clinical characteristics are summarized in Table 1. All fasting blood biochemical data from the obese group were within the normal range. According to the American Diabetes Association criteria (21) all the patients had normal glucose tolerance.

Plasma MCP-1 and CRP levels were significantly higher in obese women than in lean controls $(71.9 \pm 30.6$ vs $41.7 \pm 8.6 \mathrm{pg} / \mathrm{ml}, \quad P<0.0001$ and $1.04 \pm 0.6$ vs $0.03 \pm 0.03 \mathrm{mg} / \mathrm{dl}, P<0.0001$ respectively) (Fig. 1). In the obese group, a positive correlation between MCP-1 values and VAT $\left(r^{2}=0.57\right.$,

Table 1 Clinical and anthropometric characteristics of the study population. Data are expressed as means \pm S.D.

\begin{tabular}{lccc}
\hline & $\begin{array}{c}\text { Controls } \\
(n=15)\end{array}$ & $\begin{array}{c}\text { Obese } \\
(n=27)\end{array}$ & $\boldsymbol{P}$ \\
\hline Variable & $36.8 \pm 8.2$ & $33.3 \pm 8.3$ & $\mathrm{~ns}$ \\
Age (years) & $57.9 \pm 7.4$ & $107.6 \pm 12.0$ & $<0.0001$ \\
Weight $(\mathrm{kg})$ & $162.1 \pm 8.6$ & $157.5 \pm 4.9$ & $\mathrm{~ns}$ \\
Height $(\mathrm{cm})$ & $22.6 \pm 1.7$ & $43.5 \pm 4.8$ & $<0.0002$ \\
BMI (kg/m $\left.{ }^{2}\right)$ & $75.2 \pm 4.8$ & $116.8 \pm 12.2$ & $<0.0002$ \\
Waist (cm) & & & \\
circumference & $0.79 \pm 0.04$ & $0.86 \pm 0.1$ & $<0.03$ \\
Waist-to-hip ratio & $16.6 \pm 3.1$ & $52.3 \pm 10$ & $<0.0002$ \\
Fat mass (kg) & $40.4 \pm 5.4$ & $56.5 \pm 8.1$ & $<0.0002$ \\
Free fat mass (kg) & $117.9 \pm 6.2$ & $120.2 \pm 8.5$ & $\mathrm{~ns}$ \\
Systolic BP (mmHg) & $78.7 \pm 4.8$ & $75.5 \pm 6.6$ & $\mathrm{~ns}$ \\
Diastolic BP (mmHg) & & & \\
\hline
\end{tabular}

BMI, body mass index; BP, blood pressure; ns, not significant.
$P<0.0001) \quad$ (Fig. 2), VAT/SAT area $\left(r^{2}=0.67\right.$, $P<0.0001)$ and CRP levels $\left(r^{2}=0.48, P<0.0001\right)$ was observed. No correlation of MCP-1 with SAT, BMI, waist circumference, WHR, fat mass and fat-free mass was found. In order to emphasize the role of fat distribution, multiple stepwise regression analysis (Table 2) was used to investigate the correlations of relative indices with $\mathrm{MCP}-1$ and $\mathrm{CRP}$ levels. Plasma MCP-1 most closely correlated with VAT/SAT $\left(\mathrm{r}^{2}=0.67, \mathrm{P}<0.0001\right)$, whereas CRP was associated with VAT $\left(\mathrm{r}^{2}=0.34, P<0.002\right)$; the other indices of fat distribution did not enter the model. It is noteworthy that, when separating the obese patients on the basis of VAT area (i. e. $>130 \mathrm{~cm}^{2}(n=15)$ or $<130 \mathrm{~cm}^{2}$ $(n=12)) \quad(22)$, higher $\quad$ MCP-1 $\quad(87.9 \pm 32.7 \quad$ vs $32.7 \pm 8.7 \mathrm{pg} / \mathrm{ml}, \quad P<0.0001)$ and CRP levels $(1.38 \pm 0.55$ vs $0.61 \pm 0.32 \mathrm{mg} / \mathrm{dl}, \quad P<0.04)$ were observed in patients with higher abdominal adiposity.

\section{MCP-1 and echocardiographic parameters}

As recently reported in a similar series (15), obese patients showed an impairment of several echocardiographic parameters compared with lean subjects, and a significant correlation was detected between VAT area and some of the parameters. In the present study, MCP-1 levels were positively correlated with PW $(P<0.005)$ (Fig. 3A), LVM $(P<0.02)$ (Fig. 3B), $\mathrm{LVMh}^{2.7}(P<0.03)$, RWT $(P<0.01)$, E $(P<0.01)$, IVRT $(P<0.001)$ (Fig. 3C) and deceleration time (DT) $(P<0.01)$ and CRP levels were also positively correlated with IVRT $(P<0.003)$. No correlation of MCP1 and CRP was found with the other echocardiographic parameters. Even after correcting for increased values of VAT and CRP, a significant relationship $(P<0.05)$ between MCP-1 and some echocardiographic correlates (PW, IVRT and LVMh ${ }^{2.7}$ ) was still detected (Table 3). Moreover, PW, RWT, IVRT and DT were also higher in patients with the greatest amount of VAT.

\section{Discussion}

It seems likely that VAT may represent an endocrine organ of linkage between obesity and inflammatory pathways (23) and that adipocytes are important synthesizers of bioactive proteins $(1-4)$. Adipocytes are now known to be capable of expressing MCP-1 in the presence of serum or specific stimuli such as CRP $(24,25)$. In particular, the abdominal fat depot is a potent stimulator of CRP production by the liver and our results confirm the association between this inflammation index and VAT area (26). Epidemiological studies have shown that CRP is a strong predictor of coronary heart disease events (27) and a component of the atherothrombotic profile of abdominal obesity (26). Furthermore, patients with high CRP levels may be at risk of $L V$ dysfunction and remodeling (28). 

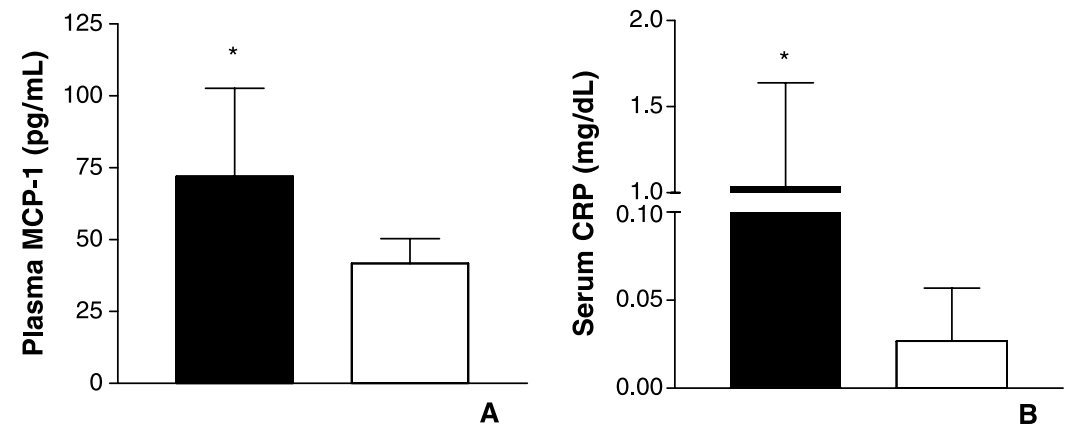

Figure 1 (A) Plasma MCP-1 and (B) serum CRP levels in obese patients (solid bars) compared with the control group (open bars). ${ }^{*} P<0.0001$.
Also, elevated MCP-1 levels are correlated with established risk factors for atherosclerosis, increased risk of death or myocardial infarction (29), and these findings reinforce the association between an inflammatory background and a poor cardiac contractile function $(30,31)$.

To the best of our knowledge, no direct association between MCP-1, VAT and echocardiographic abnormalities has been demonstrated. The increased MCP-1 levels in our obese women and the significant correlations with VAT area (32) and CRP levels may support a direct involvement of abdominal adiposity in systemic obesity-related inflammation and an enhancement of MCP-1 production by adipocytes may be supposed. The correlation here presented might be reinforced by the absence of confounding factors which were avoided during patient recruitment. In fact, our study was performed in young, pre-menopausal, normotensive, normocholesterolemic and drug-free patients, thus excluding the possibility that high MCP-1 concentrations may be associated with older age, hypertension, hypercholesterolemia and kidney failure (30). In addition, in our series all the patients had normal glucose tolerance and no correlation was observed between MCP-1 and the insulin sensitivity indices (HOMA and QUICKI) nor with basal glucose and insulin (data not shown) (33).

The finding that VAT and VAT/SAT significantly correlated with MCP-1 but not with SAT or total fat mass measured by BIA, supports the involvement of the omental and mesenteric compartments, which was confirmed when considering our results with stepwise

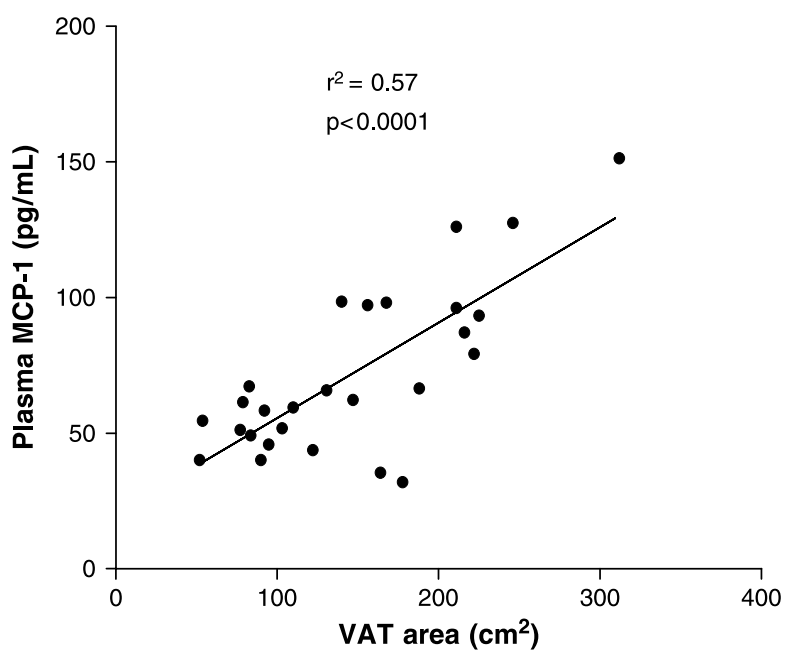

Figure 2 Correlation between plasma levels of MCP-1 and VAT area in 27 obese patients.

regression analysis. Bruun et al. were able to show that MCP-1 levels were higher in visceral obesity, but after adjusting for adipose-tissue resident macrophages, the difference disappeared. In our series of patients with morbid obesity, both visceral and subcutaneous adipose tissue are widely present, thus supporting our findings (12). Accordingly, a positive correlation between the reduction in MCP-1 levels and the decrease in visceral fat was reported in patients with metabolic syndrome (14). Of further interest is the observation that patients with a greater amount of visceral fat showed a greater

Table 2 Stepwise regression analysis (t value) of the association between some independent variables and MCP-1 and CRP levels in obese patients $(n=27)$.

\begin{tabular}{|c|c|c|c|c|c|c|c|c|c|c|c|}
\hline & $\begin{array}{l}\text { VAT } \\
\left(\mathrm{cm}^{2}\right)\end{array}$ & $\begin{array}{l}\text { SAT } \\
\left(\mathrm{cm}^{2}\right)\end{array}$ & V/S & $\begin{array}{l}\text { A.diam } \\
(\mathrm{cm})\end{array}$ & $\begin{array}{l}\text { Waist } \\
(\mathrm{cm})\end{array}$ & WHR & BMI & $\begin{array}{l}\text { BW } \\
(\mathrm{kg})\end{array}$ & $\begin{array}{l}\text { FM } \\
(\mathrm{kg})\end{array}$ & $\begin{array}{c}\text { FFM } \\
(\mathrm{kg})\end{array}$ & Model $\mathrm{R}^{2}$ \\
\hline $\begin{array}{l}\text { MCP-1 }(\mathrm{pg} / \mathrm{ml}) \\
\text { (constant value 24.7470) }\end{array}$ & 0.41 & 1.11 & $5.44^{*}$ & 1.24 & -0.12 & -1.18 & 0.32 & 0.32 & 0.39 & 0.44 & 0.62 \\
\hline $\begin{array}{l}\text { CRP (mg/dl) } \\
\text { (constant value } 0.42029 \text { ) }\end{array}$ & 2.24 ** & 0.26 & -0.39 & 1.23 & 0.13 & -2.11 & 0.53 & 0.53 & 0.86 & 1.50 & 0.22 \\
\hline
\end{tabular}

VAT, visceral adipose tissue; SAT, subcutaneous adipose tissue; V/S, VAT/SAT; A.diam, abdominal sagittal diameter; WHR, waist-hip ratio; BW, body weight; FM, fat mass; FFM, fat-free mass.

${ }^{\star} P<0.0001,{ }^{* \star} P<0.04$

www.eje-online.org 

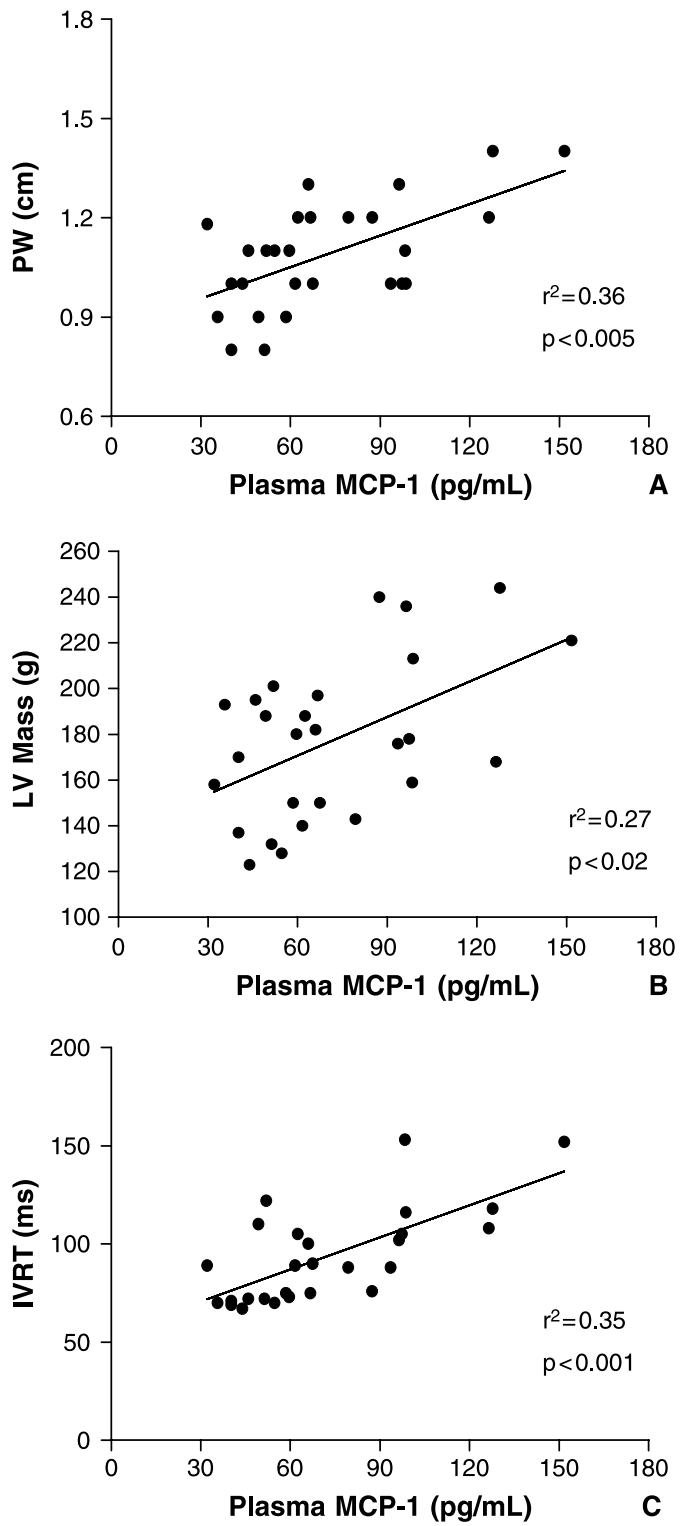

Figure 3 Correlation between MCP-1 levels and (A) posterior wall (PW), (B) left ventricular mass (LV Mass) and (C) isovolumetric relaxation time (IVRT) using the unweighted linear regression model.

MCP-1 concentration than those with a lower degree of abdominal adiposity. These data, as confirmed by stepwise regression analysis, strongly support the hypothesis that VAT is a major source of the increased levels of this cytokine.

Another issue addressed in our study concerns the involvement of the VAT-related inflammatory state with the occurrence of sub-clinical echocardiographic abnormalities. In fact, inflammatory markers are important in identifying patients with poorer contractile function and at risk of heart failure and in predicting LV remodeling $(16,28,31)$. Changes in cardiac morphology and hemodynamic parameters in normotensive
Table 3 Correlation between MCP-1 and echocardiodgraphic parameters before and after correction for increased VAT and CRP.

\begin{tabular}{llc}
\hline & \multicolumn{2}{c}{$P$ value } \\
\cline { 2 - 3 } Echocardiographic variable & Before & After \\
\hline Posterior wall thickness $(\mathrm{cm})$ & $<0.005$ & $<0.05$ \\
Relative wall thickness & $<0.01$ & $\mathrm{~ns}$ \\
LV mass $(\mathrm{g})$ & $<0.02$ & $\mathrm{~ns}$ \\
Indexed LV mass $\left(\mathrm{g} / \mathrm{m}^{2.7}\right)$ & $<0.03$ & $<0.05$ \\
Isovolumetric relaxation time $(\mathrm{ms})$ & $<0.001$ & $<0.05$ \\
Early diastolic filling wave velocity $(\mathrm{m} / \mathrm{s})$ & $<0.01$ & $\mathrm{~ns}$ \\
Deceleration time $(\mathrm{ms})$ & $<0.01$ & $\mathrm{~ns}$ \\
\hline
\end{tabular}

VAT, visceral adipose tissue; CRP, C-reactive protein; LV, left ventricle; ns, not significant.

obese patients are not new findings and the association between intra-abdominal adipose tissue and echocardiographic indices has previously been reported by us and others $(15,33)$.

The significant correlation between MCP-1 and echocardiographic parameters (PW, RWT, LVM and $\mathrm{LVMh}^{2.7}$ ) obtained in our homogeneous population, even after correction for increased VAT and CRP, may support a role for MCP-1 itself in the genesis of LV morphological changes; nevertheless, the important role of VAT in influencing cardiac abnormalities and MCP-1 levels in obese patients is further sustained by the difference found in these variables when patients are divided on the basis of a VAT cut-off value of $130 \mathrm{~cm}^{2}$.

As previously reported $(15,34,35)$, some alterations in diastolic function parameters (such as E, IVRT and DT) were detected in obese subjects and there was a relationship between MCP-1 levels, VAT and these diastolic function indices. These observations suggest that, when there is an increase in visceral adipose tissue, a long-lasting exposition to inflammatory stimuli might be responsible for a gradual impairment of both diastolic function and cardiac morphology. On the other hand, we cannot exclude the possibility that inflammatory proteins derived from perivascular and epicardial fat might also play a role in cardiac remodeling (36).

In conclusion, our findings support the hypothesis that VAT plays an important role in determining MCP-1 levels and the inflammatory state of abdominal adiposity. It is also conceivable that MCP-1 may be implicated not only in chronic, low-grade obesityrelated inflammation but also in VAT-related subclinical echocardiographic abnormalities.

\section{Acknowledgements}

This work was partially supported by grants from FIRST $60 \%$, Rome. We thank Federica Ermetici, Luisa Molinari, Daniele Passoni for their technical assistance. 


\section{References}

1 Hotamisligil GS, Shargill NS \& Spiegelman BM. Adipose expression of tumor necrosis factor alpha: direct role in obesitylinked insulin resistance. Science 1993259 87-91.

2 Fried SK, Bunkin DA \& Greenberg AS. Omental and subcutaneous adipose tissues of obese subjects release interleukin-6: depot difference and regulation by glucocorticoid. Journal of Clinical Endocrinology and Metabolism $1998 \mathbf{8 3} 847-850$.

3 Sartipy P \& Loskutoff DJ. Monocyte chemoattractant protein 1 in obesity and insulin resistance. PNAS 2003100 7265-7270.

4 Fukuhara A, Matsuda M, Nishizawa M, Segawa K, Tanaka M, Kishimoto K, Matsuki Y, Murakami M, Ichisaka T, Murakami H, Watanabe E, Takagi T, Akiyoshi M, Ohtsubo T, Kihara S, Yamashita S, Makishima M, Funahashi T, Yamanaka S, Hiramatsu R, Matsuzawa Y \& Shimomura I. Visfatin: a protein secreted by visceral fat that mimics the effects of insulin. Science $2005307426-430$.

5 Behr TM, Wang X, Aiyar N, Coatney RW, Li X, Koster P, Angermann CE, Ohlstein E, Feuerstein GZ \& Winaver J. Monocyte chemoattractant protein-1 is upregulated in rats with volumeoverload congestive heart failure. Circulation $2000 \mathbf{1 0 2}$ $1315-1322$.

6 Kolattukudy PE, Quach T, Bergese S, Breckenridge S, Hensley J, Altschuld R, Gordillo G, Klenotic S, Orosz C \& ParkerThornburg J. Myocarditis induced by targeted expression of the MCP-1 gene in murine cardiac muscle. American Journal of Pathology $1998152101-111$.

7 Damas JK, Aukrust P, Ueland T, Odegaard A, Eiken HG, Gullestad L, Sejersted OM \& Christensen G. Monocyte chemoattractant protein-1 enhances and interleukin-10 suppresses the production of inflammatory cytokines in adult rat cardiomyocytes. Basic Research in Cardiology 200196 345-352.

8 Hayashidani S, Tsutsui H, Shiomi T, Ikeuchi M, Matsusaka H, Suematsu N, Wen J, Egashira K \& Takeshita A. Anti-monocyte chemoattractant protein-1 gene therapy attenuates left ventricular remodeling and failure after experimental myocardial infarction. Circulation 2003108 2134-2140.

9 Libby P. Inflammation in atherosclerosis. Nature $2002 \mathbf{4 2 0}$ $868-874$.

10 Weisberg SP, McCann D, Desai M, Rosenbaum M, Leibel RL \& Ferrante AW. Obesity is associated with macrophage accumulation in adipose tissue. Journal of Clinical Investigation 2003 $1121796-1808$.

11 Xu H, Barnes GT, Yang Q, Tan G, Yang D, Chou CJ, Sole J, Nichols A, Ross JS, Tartaglia LA \& Chen H. Chronic inflammation in fat plays a crucial role in the development of obesity-related insulin resistance. Journal of Clinical Investigation 2003112 $1821-1830$

12 Bruun JM, Lihn AS, Pedersen SB \& Richelsen B. MCP-1 release is higher in visceral than subcutaneous human adipose tissue. Implication of macrophages resident in the adipose tissue. Journal of Clinical Endocrinology and Metabolism 20054 2282-2289.

13 Gerhardt CC, Romero IA, Cancello R, Camoin L \& Strosberg AD. Chemokines control fat accumulation and leptin secretion by cultured human adipocytes. Molecular and Cellular Endocrinology $200117581-92$.

14 Troseid M, Lappegard KT, Claudi T, Damas JK, Morkrid L, Brendberg R \& Mollnes TE. Exercise reduces plasma levels of the chemokines MCP-1 and IL-8 in subjects with the metabolic syndrome. European Heart Journal 200425 349-355.

15 Morricone L, Malavazos AE, Coman C, Donati C, Hassan T \& Caviezel F. Echocardiographic abnormalities in normotensive obese patients: relationship with visceral fat. Obesity Research $200210489-498$.

16 Marfella R, Esposito K, Siniscalchi M, Cacciapuoti F, Giugliano F, Labriola D, Ciotola M, Di Palo C, Misso L \& Giugliano D. Effect of weight loss on cardiac synchronization and proinflammatory cytokines in premenopausal obese women. Diabetes Care 2004 27 47-52.
17 Sahn DJ, Demaria A, Kisslo J \& Weyman A. The Committee on M-Mode Standardization of the American Society of Echocardiography: recommendations regarding quantitation in M-mode echocardiography: results of a survey study of echocardiographic measurements. Circulation $1978 \mathbf{5 8} 1072-1083$.

18 Devereux RB \& Reichek N. Echocardiographic determination of left ventricular mass in man: anatomic validation of the method. Circulation 197755 613-618.

19 de Simone G, Daniels SR, Devereux RB, Meyer RA, Roman MJ, de Divitiis O \& Alderman MH. Left ventricular mass and body size in normotensive children and adults: assessment of allometric relations and impact of overweight. Journal of the American College of Cardiology 199220 1251-1260.

20 Katz A, Nambi SS, Mather K, Baron AD, Follmann DA, Sullivan G \& Quon MJ. Quantitative insulin sensitivity check index: a simple, accurate method for assessing insulin sensitivity in humans. Journal of Clinical Endocrinology and Metabolism $2000852402-2410$.

21 Report of the Expert Committee on the Diagnosis and Classification of Diabetes Mellitus. Diabetes Care 200326 (Suppl 1) S5-S20.

22 Williams MJ, Hunter GR, Kekes-Szabo T, Nicholson C \& Berland L. Intra-abdominal adipose tissue cut-points related to elevated cardiovascular risk in women. International Journal of Obesity and Related Metabolic Disorders 199620 613-617.

23 Wellen KE \& Hotamisligil GS. Obesity-induced inflammatory changes in adipose tissue. Journal of Clinical Investigation 2003 112 1785-1788.

24 Rollins BJ. Chemokines. Blood 199790 909-928.

25 Pasceri V, Chang JS, Willerson JT, Yeh ET \& Chang J. Modulation of C-reactive protein-mediated monocyte chemoattractant protein-1 induction in human endothelial cells by anti-atherosclerosis drugs. Circulation 2001103 2531-2534.

26 Lemieux I, Pascot A, Prud'homme D, Almeras N, Bogaty P, Nadeau A, Bergeron J \& Despres JP. Elevated C-reactive protein: another component of the atherothrombotic profile of abdominal obesity. Arteriosclerosis, Thrombosis, and Vascular Biology 200121 961-967.

27 Speidl WS, Graf S, Hornykewycz S, Nikfardjam M, Niessner A, Zorn G, Wojta J \& Huber K. High-sensitivity C-reactive protein in the prediction of coronary events in patients with premature coronary artery disease. American Heart Journal $2002 \mathbf{1 4 4}$ $449-455$.

28 Morishima I, Sone T, Tsuboi H, Kondo J, Mukawa H, Kamiya H, Hieda N \& Okumura K. Plasma C-reactive protein predicts left ventricular remodeling and function after a first acute anterior wall myocardial infarction treated with coronary angioplasty: comparison with brain natriuretic peptide. Clinical Cardiology $200225112-116$

29 de Lemos JA, Morrow DA, Sabatine MS, Murphy SA, Gibson CM, Antman EM, McCabe CH, Cannon CP \& Braunwald E. Association between plasma levels of monocyte chemoattractant protein-1 and long-term clinical outcomes in patients with acute coronary syndromes. Circulation 2003107 690-695.

30 Torre-Amione G, Kapadia S, Benedict C, Oral H, Young JB \& Mann DL. Proinflammatory cytokine levels in patients with depressed left ventricular ejection fraction: a report from the Studies of Left Ventricular Dysfunction (SOLVD). Journal of the American College of Cardiology 199627 1201-1206.

31 Vasan RS, Sullivan LM, Roubenoff R, Dinarello CA, Harris T, Benjamin EJ, Sawyer DB, Levy D, Wilson PW \& D'Agostino RB. Framingham Heart Study. Inflammatory markers and risk of heart failure in elderly subjects without prior myocardial infarction: the Framingham Heart Study. Circulation 2003107 $1486-1491$.

32 Malavazos AE, Cereda E, Morricone L, Corsi MM \& Ambrosi B. Monocyte chemoattractant protein 1 (MCP-1) and visceral fat. Journal of Clinical Endocrinology and Metabolism 2005903128.

33 Piemonti L, Calori G, Mercalli A, Lattuada G, Monti P, Garancini MP, Costantino F, Ruotolo G, Luzi L \& Perseghin G. Fasting plasma leptin, tumor necrosis factor-alpha receptor 2, and monocyte chemoattracting protein 1 concentration in a 
population of glucose-tolerant and glucose-intolerant women: impact on cardiovascular mortality. Diabetes Care 200326 2883-2889.

34 Nakajima T, Fujioka S, Tokunaga K, Matsuzawa Y \& Tarui S. Correlation of intraabdominal fat accumulation and left ventricular performance in obesity. American Journal of Cardiology 198964 $369-373$.

35 Iacobellis G, Ribaudo MC, Leto G, Zappaterreno A, Vecci E, Di Mario U \& Leonetti F. Influence of excess fat on cardiac morphology and function: study in uncomplicated obesity. Obesity Research $200210767-773$.
36 Mazurek T, Zhang L, Zalewski A, Mannion JD, Diehl JT, Arafat H, Sarov-Blat L, O'Brien S, Keiper EA, Johnson AG, Martin J, Goldstein BJ \& Shi Y. Human epicardial adipose tissue is a source of inflammatory mediators. Circulation. $2003 \mathbf{1 0 8}$ 2460-2466.

Received 8 June 2005

Accepted 1 September 2005 